\author{
Luka Vidmar
}

\title{
Tine Germ: Smrt kraljuje povsod in bela Smrt triumfira: Valvasorjevo Prizorišče človeške smrti v evropskem kontekstu
}

Ljubljana: Znanstvena založba Filozofske fakultete Univerze v Ljubljani, 2015, 176 strani, 68 ilustracij

Umetnostni zgodovinar Tine Germ je v zadnjih letih Valvasorjevemu delu Theatrum mortis humanae tripartitum iz leta 1682 posvetil vrsto raziskav, njihove ugotovitve pa je leta 2015 razširil in povezal še v monografijo Smrt kraljuje povsod in bela Smrt triumfira. Raziskave so bile vsekakor potrebne: Prizorišče človeške smrti je bilo namreč do tedaj v slovenski umetnostni, literarni in kulturni zgodovini kljub pomembnosti avtorja in kljub primerljivosti z najkvalitetnejšimi sorodnimi deli iz drugih evropskih dežel skoraj prezrto ali vsaj zelo pomanjkljivo obravnavano. Raziskave so bile tudi uspešne: prvič so prinesle poglobljeno ikonografsko analizo omenjenega polihistorjevega dela in prvič obširneje opisale njegovo mesto $\mathrm{v}$ sočasni evropski likovni in literarni umetnosti. Iz uvoda k monografiji Smrt kraljuje povsod in bela Smrt triumfira je jasno razvidno, da je bilo to mogoče najprej zato, ker je avtor kritično dekonstruiral tradicionalne paradigme, zlasti (umetnostnih ali literarnih) »centrov« oziroma »obrobij«, pa tudi (slogovne ali idejne) »naprednosti« oziroma »zaostalosti«, ki so v humanističnih vedah ovirale in v določeni meri še vedno ovirajo neobremenjeno raziskovanje del, kakršno je Prizorišče človeške smrti. Germova monografija nas tako že na začetku implicitno opozarja, da čaka na temeljitejšo znanstveno obravnavo še veliko umetniških in literarnih del, nastalih na Slovenskem v srednjem in zgodnjem novem veku, ki smo jih puščali ob strani zaradi različnih predsodkov, oblikovanih $\mathrm{v}$ 19. in 20. stoletju.

Germ Valvasorjevo delo pravilno uvrsti v tedaj modni knjižni žanr moralnodidaktičnega "prizorišča" in ga opredeli kot »likovno-literarni memento mori«, namenjen navajanju bralca $\mathrm{h}$ krepostnemu in pobožnemu življenju, s tem pa $\mathrm{k}$ zveličanju po smrti. Prav tako razloži trodelno zasnovo dela (Saltus mortis, Varia genera mortis, Poenae damnatorum) ter definira njegove likovne in literarne vire, pri čemer zavestno preseže »klasične«, v resnici pa anahronistične očitke starejših umetnostnih zgodovinarjev o zastarelosti in zaostalosti ilustracij, v veliki meri oprtih na tradicijo 16. stoletja. Posebej pomembno za nadaljnje raziskave je razločevanje 
zgledov iz nemške in italijanske renesanse za Valvasorjeva umetnostna sodelavca Janeza Kocha kot avtorja velikega števila predlog in Andreja Trosta kot bakrorezca. Sledi ikonografska analiza monumentalnega uvodnega bakroreza Zmagoslavje Smrti, ki prepričljivo zavrne starejše izpeljevanje te podobe iz pasijonskih procesij in dokaže njen izvor v Petrarkovem in petrarkističnem motivu triumfa. Germ v nadaljevanju obravnava prvi, najobsežnejši in $\mathrm{v}$ dosedanji strokovni literaturi najvidnejši del Valvasorjeve knjige - Mrtvaški ples. Zavrne starejšo razlago, da so te ilustracije posnetki ali celo kopije znamenitega lesoreznega cikla Hansa Holbeina mlajšega (prva izdaja iz leta 1538), in dokaže, da se v resnici zgledujejo po knjigi Imagines mortis Arnolda Birckmanna (prva izdaja iz leta 1555), ki je izšla iz Holbeinove tradicije. S podrobno primerjavo Holbeinove, Birckmannove in Valvasorjeve izdaje pokaže na vrsto podobnosti in razlik. Za razumevanje specifičnega duhovnega, kulturnega in umetnostnega dogajanja v habsburški monarhiji (ne le na Kranjskem), ki so ga v 17. stoletju zaznamovali poudarjeno katoliški procesi in pojavi protireformacije, verske obnove in politike pod geslom Pietas Austriaca, so zelo koristni podatki o posebnostih Prizorišča človeške smrti, na primer težnja k večji dekorativnosti ozadja ilustracij, omilitev potencialno versko in moralno spornih mest zaradi cenzure ipd.

Monografija se v nadaljevanju posveti drugemu delu Valvasorjeve knjige (Različne vrste smrti), ki je tako dočakal prvo resno obravnavo. Pri vsakem bakrorezu Germ pazljivo razbira vsebinske in likovne vire, na primer Gottfriedovo Zgodovinsko kroniko, rekonstruira način sodelovanja ustvarjalcev, tudi posamezna neujemanja med napisi in ilustracijami, posrečeno pojasnjuje vodilne ideje cikla, na primer o neizbežnosti smrti in nujnosti zglednega življenja, in opozarja na izvirna razhajanja z literarno in likovno tradicijo, na primer na aktualne zgodbe iz soseščine Kranjske. Zadnji del monografije se ukvarja $\mathrm{z}$ bogatimi bordurami, s katerimi je Trost prizadevno obdal prizore smrti, ki pa niso bile deležne nikakršne pozornosti stroke. Germ, vidno močan na področju ikonografije flore in favne, se v tem poglavju posebej izkaže, saj tudi v drobnih upodobitvah živali in rastlin, ki imajo na videz le dekorativno vlogo, odkriva osupljivo skrbno zamišljeno simboliko minljivosti življenja in večnosti kreposti. Tem prikazom, ki na več mestih dobivajo celo podobo znanih basni, prepričljivo določi vzore, na primer ilustracije flamskega slikarja Georga Hoefnagla.

Smrt kraljuje povsod in bela Smrt triumfira je tako odlična študija o Valvasorjevem Prizorišču človeške smrti, ki po Germovi zaslugi ni več zapostavljeno. Monografije pa ne odlikuje le velika količina na novo pridobljenih izvirnih spoznanj, temveč tudi lep in razumljiv jezik - obe potezi danes v humanistiki žal nista več samoumevni. Zato ni presenetljivo, da je monografija že postala ena glavnih novejših opor za raziskovanje Valvasorjevih izdajateljskih podvigov in ustvarjalnosti njegovega kroga umetnikov. Upamo lahko, da bo spodbudila tudi nove obravnave še tretjega dela Prizorišča 
človeške smrti - Muk pogubljenih. Vsekakor pa nas bo v prihodnjih raziskavah baroka opominjala na skrbno upoštevanje njegovih bistvenih plasti: vsebin srednjeveškega krščanstva, form antičnega Rima in renesanse ter prikazovanja Boga, človeka in sveta na bolj čuten in dramatičen način, ki je prinesel tudi novo tematizacijo minljivosti in poti k zveličanju. 